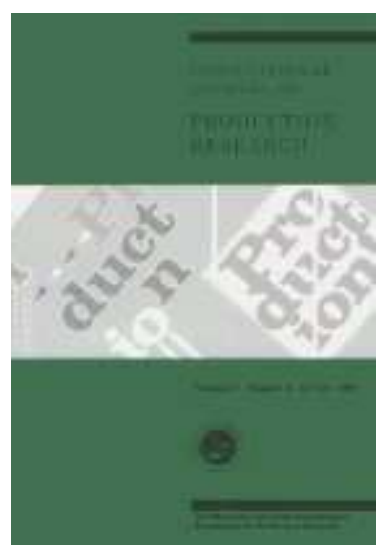

\title{
Proactive environmental strategy in a supply chain context: The mediating role of investments
}

\begin{tabular}{|r|l|}
\hline Journal: & International Journal of Production Research \\
\hline Manuscript ID: & TPRS-2010-IJPR-0588.R1 \\
\hline Manuscript Type: & Original Manuscript \\
\hline Author: & $19-$ Oct-2010 \\
\hline Complete List of Authors: & $\begin{array}{l}\text { Ates, Melek; Rotterdam School of Management, Erasmus } \\
\text { University, Management of Technology and Innovation } \\
\text { Bloemhof, Jacqueline; Wageningen University, Department of } \\
\text { Logistics, Decision and Information Sciences } \\
\text { van Raaij, E; Erasmus University, Rotterdam School of Management } \\
\text { Wynstra, F; Erasmus University, Rotterdam School of Management }\end{array}$ \\
\hline Keywords: & $\begin{array}{l}\text { ENVIRONMENTAL MANAGEMENT, SUPPLY CHAIN MANAGEMENT, } \\
\text { EMPIRICAL STUDY, STRUCTURAL EQUATION MODELLING }\end{array}$ \\
\hline Keywords (user): & $\begin{array}{l}\text { proactive environmental strategy, environmental investments, } \\
\text { supply chain, Structural equation modelling, Turkey }\end{array}$ \\
\hline \multicolumn{2}{|l}{} \\
\hline
\end{tabular}

\section{SCHOLARONE" Manuscripts}




\title{
Proactive environmental strategy in a supply chain context: The mediating role of investments
}

\author{
Melek Akın Ateş ${ }^{* a}$, Jacqueline Bloemhof ${ }^{b}$, Erik van Raaij ${ }^{a}$ and Finn Wynstra ${ }^{a}$ \\ ${ }^{a}$ Department of Management of Technology and Innovation, Rotterdam School of \\ Management, Erasmus University, Rotterdam, The Netherlands. \\ ${ }^{b}$ Department of Logistics, Decision and Information Sciences, Wageningen University, The \\ Netherlands
}

* Corresponding author. Email: makin@rsm.nl, tel. 31104081636 , fax. 31104089014 


\title{
Proactive environmental strategy in a supply chain context: The mediating role of investments
}

\begin{abstract}
There is a growing body of knowledge on the link between environmental management and supply chain management, but there is contradicting evidence on the impact of a proactive environmental strategy on environmental performance. Therefore, this paper investigates the impact of proactive environmental strategy on environmental performance as mediated by environmental investments. We also consider the antecedents of the adoption of proactive environmental strategy. We develop and test hypotheses, using data collected from 96 Turkish manufacturers through an online questionnaire. The model was tested using Partial Least Squares (PLS), a structural equation modelling method. The results show that a proactive environmental strategy leads to higher environmental investments; both internally and externally in collaboration with suppliers. Our findings support our hypothesis that environmental investments acts as a mediating variable between proactive environmental strategy and environmental performance. The results also show that customer pressure and, particularly, organizational commitment positively impact the extent to which firms adopt a proactive environmental strategy.
\end{abstract}

Keywords: proactive environmental strategy, environmental investments, supply chain, structural equation modelling, Turkey.

\section{Introduction}

Increasing awareness of environmental problems such as depletion of natural resources and climate change has created a new competitive environment for firms where they are forced to include environmental concerns of different stakeholders into their corporate agenda (Beamon, 1999; Vachon and Klassen, 2007). Among these stakeholders, governments and other regulatory forces traditionally have a substantial influence on firms by making them comply with environmental regulations and decrease their burden on the environment (Banerjee, 2001; Walker et al., 2008). However, in line with the growing importance of the issue, the motives behind environmental management are changing. Pressures from 'green consumers', business customers, suppliers and other stakeholders are driving firms to be more environmentally conscious and to adopt more proactive environmental strategies that go beyond mere compliance with laws and regulations. Moreover, in addition to external pressures, internal mechanisms also foster this process, and forward-thinking firms adopt proactive strategies not just to improve their environmental performance, but also to gain and maintain competitive advantage (Theyel, 2001; Zhu et al., 2008b).

The motive behind the adoption of a more proactive environmental strategy has been stressed as achieving improved environmental performance (Klassen and Whybark, 1999; Russo and Fouts, 1997), yet there are still contradictory findings as to whether this improved performance is actually achieved (Lee and Rhee, 2007). One possible explanation for that is the omission of a crucial mediating variable in this relationship: environmental investments. Contingency theory suggests that both the formation and implementation parts of strategy needs to be considered while analyzing performance (Ginsberg and Venkatraman, 1985). One way the environmental strategy is translated into actions is through environmental investments. Yet, there has been limited research that examines the relationships among environmental management, realisation of environmental investments, and performance outcomes. Some prior studies suggest that even though firms are becoming increasingly proactive with respect to their environmental policy and strategy, this awareness does not always result in investing more time and money in environmental issues (Cordeiro and Sarkis, 1997; Aragon-Correa and Rubio-Lopez, 2007). This may explain why environmental strategies are not always resulting in a higher environmental performance. In this research, we aim to fill this gap by testing the mediating role of environmental investments. 
Whereas these investments can be internal investments of firms, they can also take the form of investments in collaboration with external parties such as suppliers. Proactive strategies are more comprehensive and socially more complex processes than compliance, and require investing in supplier integration (Russo and Fouts, 1997; Klassen and Vachon, 2003). As the environmental performance of the suppliers has a direct impact on the products of the buying firm, assurance of the same level of environmental awareness and consistency in environmental capabilities is needed. Therefore, proactive firms invest in their suppliers to improve their own environmental performance (Theyel, 2001). Investments with suppliers may take the form of joint problem-solving sessions, information sharing, establishing common goals, personnel and equipment sharing, and evaluating the suppliers (Vachon and Klassen, 2006; Zsidisin and Siferd, 2001). Such external investments can also affect the environmental performance of the focal firm (Theyel, 2001).

While the main focus of this research is on the implementation part of proactive environmental strategies, we also examine two main antecedents of a proactive environmental strategy: customer pressure and organizational commitment. In addition to considering the role of suppliers, a proactive environmental strategy also requires investigating the role of customers. Many authors stress that customer pressure fosters more proactive environmental strategies (Delmas and Toffel, 2004; González-Benito and González-Benito, 2006; Henriques and Sadorsky, 1999). Some studies suggest that customer pressure can also stimulate a reactive approach in some firms and increase environmental investments as a quick response to the customer demand (Liu and $\mathrm{Wu}, 2009$ ), without necessarily resulting in the formation of a proactive strategy.

Bowen et al. (2001b) identify organizational commitment as a possible explanation for the different and diverging environmental strategies of the firms which operate in the same industry. Examining organizational commitment allows us to compare the effects of internal versus external factors driving proactive environmental strategy. There is a growing body of research about the link between environmental management and supply chain management which are examined under the concepts such as green supply chain management (Srivastava, 2007) and closed loop supply chains (Bloemhof-Ruwaard et al., 2004). However, the focus of that research has mostly been on environmentally sound practices in the supply chain per se rather than investigating the factors which enable or drive these advanced environmental practices to occur. Surely there are more contingencies that affect the adoption of a proactive environmental strategy, but previous literature has suggested customer pressure and organizational commitment as dominant factors (Bowen et al., 2001a; Elkington, 1994; Klassen, 2001).

In sum, we examine the following research questions in this study:

1) What is the role of environmental investments in the relationship between the adoption of proactive environmental strategies and environmental performance?

2) How do organizational commitment and customer pressure affect the adoption and implementation of proactive environmental strategies?

In the remainder of the paper, we first review the literature on environmental strategies and environmental performance, and present our hypotheses related to this causal chain. Then, we examine an internal enabler (organizational commitment) and an external driver (customer pressure) of proactiveness and we finalize our conceptual model. After that, we present our research methods and report on the analysis of data collected through an online survey and analyzed using partial least squares (PLS) method. Given the lack of studies on the relationships between corporate environmental practices and supply chains particularly in developing countries (Zhu and Sarkis, 2007), we collect data in a developing economy, with manufacturing firms in Turkey. Finally, we discuss our findings and limitations as well as our suggestions for further research. 


\section{Proactiveness, environmental investments and environmental performance}

Environmental strategies consist of a set of objectives, plans, and mechanisms that determine the responsiveness of firms to environmental issues (Klassen, 2001). A company faces a number of strategic options when it responds to environmental issues (Banerjee, 2001). Some companies find it sufficient to comply with laws and regulations and react to environmental issues when it is necessary, whereas others approach the subject more strategically and implement more proactive environmental strategies. Literature provides various classifications specifying the different strategies on the proactive-reactive continuum (Hart, 1995; Lee and Rhee, 2007; Walton et al., 1998; Welford, 1995).

Before considering its antecedents and consequences, it is important to define what a proactive environmental strategy is. We define our first construct, Proactive Environmental Strategy, as the set of environmental objectives, plans and procedures of a firm, which go beyond basic compliance to laws. Firms adopting proactive environmental strategies anticipate new environmental issues, are motivated by new opportunities, move ahead of public concerns, implement voluntary environmental issues and integrate those issues across functions (González-Benito, 2008; Klassen and Angell, 1998). Regulations are accepted as a baseline by proactive firms, and they constantly aim to exceed current regulations (Marshall et al., 2005). Reactive environmental strategies, on the other hand, are defined as short-term compliance strategies which do not require the firm to develop expertise or skills in managing new environmental technologies or processes (Hart, 1995). Among the major environmental concerns of a firm with a reactive environmental strategy is compliance with regulations (Lee and Rhee, 2007).

\subsection{Proactiveness and environmental performance}

The second construct in our study, Environmental Performance, is defined as the reduction of environmental impact by reducing material use, waste, and energy use. Proactive environmental strategies are often associated with higher environmental performance of the firms (Klassen and Whybark, 1999; Russo and Fouts, 1997; Vachon and Klassen, 2008). Increasingly, many firms are shifting to proactive environmental management; partly driven by a search for competitive advantage. Russo and Fouts (1997) argue that proactive environmental management relies on strategic resources and delivers efficiency and competitive advantage to the firm.

In contrast, there are also studies which failed to detect any differences in environmental and financial performance between environmental strategies. Lee and Rhee (2007) argue that the conflicting results might be due to sectoral differences or the omission of other variables that can impact the direction and value of the relationship between environmental strategies and firm performance.

Among these omitted variables, the most salient one is environmental investments. Even though there is evidence that firms are becoming increasingly proactive with respect to their environmental policy and strategy, studies indicate that this awareness does not necessarily result in investing more time and money in environmental issues (Cordeiro and Sarkis, 1997; Aragon-Correa and Rubio-Lopez, 2007). Previously, studies about proactive environmental management focused mostly on the antecedents - especially external and uncontrollable factors, and little emphasis has been put on the consequences such as environmental investments which actually enable higher environmental performance.

Another issue contributing to the confusion regarding the link between proactive environmental strategies and environmental performance is how strategy is defined. The tendency has been to include both the strategy formation and implementation parts in one single construct (Sharma and Vredenburg, 1998) and sometimes even the outcome variables such as less toxic chemical emissions (Cordeiro and Sarkis, 1997). Klassen and Whybark

http://mc.manuscriptcentral.com/tprs Email: ijpr@lboro.ac.uk 
(1999) also note that understanding of the relationships among environmental management, implementation of technologies, and performance outcomes remains quite limited.

Considering this from a more general point of view, we argue that in order for strategies to result in a higher performance for the firms, implementations and actions are needed (Ginsberg and Venkatraman, 1985). For instance, having a cost-efficiency objective does not necessarily mean that the firm will have a higher financial performance unless they invest time and effort in cost analyses, cut costs throughout the supply chain, and constantly look for improvement areas. Likewise, we argue that the missing link in the causal chain between proactive environmental strategy and environmental performance is 'environmental investments', which help leveraging goals and objectives into higher performance outcomes.

\subsection{Environmental investments as a mediator}

In order to explain the role of environmental investments as a mediator in the proactive environmental strategy and environmental performance link, we refer to contingency theory. Contingency theory explains performance within a systems model composed of three parts: input, process and output. Based on this view, processes and actions have a major role in establishing the relationship between strategy and performance (Ginsberg and Venkatraman, 1985). Researchers argue that instead of treating strategy as a variable directly influencing performance, both the formulation and implementation aspects need to be considered; not separately but in relation to each other (Dobni and Luffman, 2003; Ginsberg and Venkatraman, 1985). By making a similar distinction, Snow and Hambrick (1980) argue for the difference between intended and realized strategies and state that intended strategies might not be realized in all cases depending on the differences in implementation.

Even though this issue has been extensively debated in organization studies, there is limited research in the operations management field that directly examines the relationship between strategy, actions and performance. Rodrigues et al. (2004) are one of the few who make use of the strategy-actions-performance paradigm. They analyze relational strategy as the antecedent of information and measurement systems, which in turn are antecedents of internal and external operations. Internal and external operations are similar to our environmental construct since it is modelled as impacting the logistics performance. Another example is provided by Boyer (1998) who examines a manufacturing plant's strategy in relation to the key investments that the plant made in both structural (i.e. technology and facilities) and infrastructural (i.e. workforce and organization) improvements. Klassen and McLaughlin (1996) state that similar evidence has been lacking for environmental management. In this research, we aim to fill this gap by investigating the link between proactive environmental strategies, environmental investments and environmental performance.

According to Klassen and Whybark (1999), investments in environmental technologies significantly affect both manufacturing and environmental performance. For proactive environmental strategies to result in higher environmental performance, one could argue that these strategies should be turned from 'rhetoric' into 'reality' by means of concrete environmental investments. Rhee and Lee (2003) define this reality as "realized decisions to deploy resources and commitment to environmental management, and the specific elements of environmental management in practice" (p.177). They stress the importance of environmental investments and product and process modifications for achieving higher environmental performance. Rhee and Lee (2003) further state that one of the most important indicators of the intensity or depth of environmental strategy is the level of resource investment in environmental technology. As proactive environmental strategies are associated with considering many environmental areas and in a more extensive way, one would expect more environmental investments that would enable management of those different environmental 
objectives and areas. This, certainly, also requires considering the suppliers whose inputs have a direct effect on the subsequent processes and outputs of the buying firm (Zsidisin and Siferd, 2001).

\subsection{Internal and external environmental investments}

We define Environmental Investments as the combination of Internal Investmentsfirm internal investments in the areas of environmental design, production and logistics-and External Investments - investments in collaboration activities with suppliers, related to the same areas of environmental design, production and logistics. If a firm has a more proactive environmental strategy, then it would also invest in more strategic areas such as sustainable and greener practices that go beyond regulations and pollution prevention techniques (Klassen and Vachon, 2003). This requires considering other parties in the supply chain, especially the suppliers. In that sense, we argue that while assessing environmental investments, not only the company-specific, internal investments, but also external investments such as those related to or done with suppliers need to be considered.

Such investments with suppliers may take the form of joint problem-solving sessions, information sharing, establishing common goals, personnel and equipment sharing, and evaluating the suppliers (Vachon and Klassen, 2006; Zsidisin and Siferd, 2001). As the environmental performance of the suppliers has a direct impact on the products of the buying firm, it is of crucial importance to assure the same level of environmental awareness and consistency in environmental capabilities. These investments can also be considered as an element of supplier development. The most common ways of supplier development are direct investments in equipment and personnel at suppliers, visiting suppliers' plants, and evaluating supplier performance (Carr and Kaynak, 2007; Humphreys and Chan, 2004). Empirical evidence indicates that supplier development has positive effects on both a buyer's product quality and financial performance (Carr and Kaynak, 2007). In the case of investments related to environmental management, investing time and resources in suppliers is likely to result in more environmentally friendly products and increased environmental awareness at suppliers, which subsequently improves the buying firm's environmental performance.

Some studies also indicate a link between internal and external investments, suggesting that the latter fosters the former (Klassen and Vachon, 2008). Although there is some merit in that claim of causality, it is also argued that collaborative environmental activities with suppliers does not result in pollution prevention directly in the buying firm, but instead in the suppliers (Klassen and Vachon, 2003). In this study, we prefer to treat these two types of investments as different but related dimensions that represent distinct facets of a higher-order construct. Higher-order constructs allow for more theoretical parsimony and reduce model complexity (Edwards, 2001). Additionally, as our interest is in testing environmental investments as a mediator, and not in unravelling the causal link between the two types of investments, we combine these two concepts in a second-order latent construct.

In line with the above arguments, we propose the following hypotheses:

Hypothesis 1: Environmental Investments has a positive effect on Environmental Performance.

Hypothesis 2: Proactive Environmental Strategy has a positive effect on Environmental Investments.

\section{Antecedents of proactive environmental strategy}

Based on institutional and evolutionary theories, environmental management literature has discussed that firms are likely to widen the range of environmental decisions and deepen 
the environmentally friendly practices over time, and as a result many firms are becoming more proactive (Lee and Rhee, 2007). However, it is clear that not every company has the same level of proactiveness towards environmental management, even in the same industry (Banerjee, 2001). There are various institutional pressures coming from different stakeholders, which impact firms' adoption of environmental practices and the relationships between adopted practices and performance (Gonzáles-Benito and Gonzáles-Benito, 2006; Henriques and Sadorsky, 1999; Zhu and Sarkis, 2007).

Henriques and Sadorsky (1999) group these stakeholders into four: regulatory, organizational, community stakeholders, and the media. They state that since proactive companies are likely to be leaders in the management of environmental issues, they might not view regulatory stakeholders as being as important and they might also be likely to have influence over the regulatory process in some cases which lessens the perceived pressures associated with this stakeholder group. Additionally, regulatory forces can not be a reason to explain the differences between firms operating in the same industry since, typically, they all need to comply with the same rules. On the other hand, organizational stakeholders including customers, suppliers, employees and shareholders, are therefore likely to have more influence on the proactive environmental strategies of the firms.

As our study looks at the supply chain context, suppliers and customers are the most relevant stakeholders. Of these two, the most powerful and highly cited stakeholders are customers. Suppliers are less likely to exert pressure and put requirements on their customers, and typically only if they are much bigger than the customer firm (Hill, 1997; Walker et al., 2008). In this study, we therefore analyze the impact of customer pressure as the external driver of proactive environmental strategies by firms.

However, not only external pressures foster the adoption of a proactive environmental strategy. Based on the resource-based view of the firm, literature suggests that also internal resources and firm's capabilities help explain differences in firm's environmental strategies and performance (Lee and Rhee, 2007). Firms are more likely to have proactive environmental strategies if there is a high commitment of managers and they interpret environmental issues as opportunities (Sharma, 2000). In this study, we do not only consider commitment of top management, but also take into account the involvement of employees, who are also identified as an important organizational stakeholder in affecting environmental strategies (Henriques and Sadorsky, 1999). We argue that organizational commitment is a strong internal enabler of proactive environmental strategy.

Thus, we assess two main antecedents of proactive environmental strategy: customer pressure, as the most influential driver, and organizational commitment, as the most important enabler.

\subsection{Customer pressure}

We define Customer Pressure as the requests and requirements of end consumers and business customers on the firm to reduce environmental impact. The degree of different levels of stakeholders' demands and threats an organization faces vary according to their power (Bakker and Nijhof, 2002). In terms of affecting the corporate environmental strategies of firms, customers do seem to have a major stake irrespective of their relative size and power. Customers are cited as one source of non-regulatory pressure for environmental management in many industries and they are increasingly demanding that manufacturing firms minimize any negative impact of their products and operations on the natural environment (Hall, 2000; Klassen, 2001).

One of the most significant pressures forcing firms into addressing environmental concerns is the emergence of the 'green consumer' (Elkington, 1994). However, it is not only the end-customer who puts forward its environmental concerns, but also the industrial 
(business-to-business) customers who demand that goods and supplies they buy be environmentally sound by asking for more detailed information on the processes used and products made by suppliers (Gupta, 1995).

The changing attitude of customers towards being 'greener' also captured the attention of plant managers and encouraged greater environmental investment (Klassen and Vachon, 2003). Consistent with this, Cox et al. (1999) found in their research that although recycling materials were more expensive, one of the most important reasons given by the investigated companies for continued use of recycled materials was requirements from their industrial customers. Similarly, Zhu and Sarkis (2007) state that it were customers who encouraged Chinese suppliers to implement green supply chain management practices and make investments. In line with these observations, we argue that customers have a considerable impact on environmental investments.

Henriques and Sadorsky (1996) posit that customer pressure is a major determinant of whether the firms have an environmental plan. In other words, customer pressure may define the extent of environmental strategies of the firms. Many authors stress that customer pressure is associated with more proactive environmental strategy (Delmas and Toffel, 2004; González-Benito and González-Benito, 2006; Henriques and Sadorsky, 1999). One can argue that customer pressure is a driver which initiates and motivates firms to implement proactive environmental strategies. On the other hand, Buysse and Verbeke (2003) were not able to find a relationship between customer pressure and environmental proactiveness.

In the majority of these studies, customer pressure is defined as the pressure from industrial customers rather than from end customers (consumers), whereas some studies do not make a clear distinction between the two. In our study, we refrain from making a distinction as the firms in our sample have both industrial customers and private consumers as their clients.

Combining these two arguments results in a model where the direct and indirect effects of customer pressure on environmental investments are assessed. Literature shows strong evidence that customer pressure leads to more environmental investments. However, it is not clear whether customer pressure impacts environmental investments directly or indirectly. An indirect effect can be observed if customer pressure leads to the adoption of a proactive environmental strategy which in turn facilitates more environmental investments. In other words, customer pressure is 'enacted', and results in the adoption of a proactive environmental strategy (albeit in reaction to an external factor).

On the other hand, customer pressure may also cause higher investments by itself as a immediate response to customer requirements which would then be a direct effect, indicative of a reactive approach. In this situation, customer pressure is not enacted in proactive strategy, and investments are made out of necessity and not out of 'conviction'. Comparing these direct and indirect effects could inform us about the relative importance of formulating and adopting a proactive strategy for actually making environmental investments. Thus, we formulate the following hypotheses:

Hypothesis 3: Customer Pressure has a positive effect on Environmental Investments. Hypothesis 4: Customer Pressure has a positive effect on Proactive Environmental Strategy.

\subsection{Organizational commitment}

Literature adopting the resource-based view of the firm suggests that organizational capabilities play a major role in the environmental strategies of the firms and impact their environmental performance. Capabilities include internal and external organizational skills, resources, and functional competences developed within firms (Bowen et al., 2001b; Lee and 
Klassen, 2008). Russo and Fouts (1997) state that organizations possessing greater capabilities and resources can more easily adopt proactive environmental management practices.

Among these resources, organizational commitment is highlighted in many studies. We define Organizational Commitment as the intention and willingness of the managers and employees in a firm to be engaged in environmental management and to reduce environmental impact. Bowen et al. (2001b) identify organizational commitment as one possible explanation for the different and diverging environmental strategies of the firms which operate in the same industry. Organizational commitment is usually considered as top management's interpretations, attitudes, and perceptions towards environmental management (Aragón-Correa and Sharma, 2003). The link between proactive environmental strategies and top management support has been investigated in several studies (Berry and Rondinelli, 1999; Marshall et al., 2005; Lee and Rhee, 2007). Two arguments by González-Benito and González-Benito (2006) explain the link between support and commitment of top management, and the development of proactive environmental strategies. Firstly, the resources required for the implementation of environmental practices will be more easily available if the major person responsible for the resources supports the plans. Secondly, collaboration and coordination of different departments about environmental issues and actions becomes easier when such initiatives are endorsed from the top.

However, it should be noted that in addition to the commitment of top management, commitment of other employees and cross-functional integration in the whole organization would be needed in order to adopt and implement a proactive environmental management strategy. Proactive environmental strategies are more innovative by their nature and they can call for a change in the organizational culture and require the involvement of all organizational members (Green et al., 1998; Lamming and Hampson, 1996). Daily and Huang (2001) also analyze this issue from an innovation perspective, stating that management and employee support is a critical element of adoption and implementation of innovations in an organization, especially proactive environmental systems. Thus, in addition to the commitment of top management, lower-level management and employees' involvement are suggested by researchers and practitioners to be important in successful implementation of environmental practices (Bowen et al., 2001a; Carter et al., 1998). Therefore, in this study we focus on organizational commitment, rather than just top management support as an enabler that assists firms in adopting and implementing proactive environmental strategies.

In line with the above arguments, we propose the following hypothesis:

Hypothesis 5: Organizational Commitment has a positive effect on Proactive Environmental Strategy.

In contrast with Customer Pressure, we do not expect a direct effect of Organizational Commitment on Environmental Investments. If there is Organizational Commitment, it is highly unlikely that Environmental Investments are not guided by Proactive Environmental Strategy.

Combining all five hypotheses results in the conceptual model depicted in Figure 1.

--- Insert Figure 1 about here --- 


\section{Research Methods}

In this part of this study, we explain the recruitment of participants, development of the questionnaire, and the procedures for data analysis.

\subsection{Recruitment of participants}

The field study called for the collection of data from key informants who are knowledgeable about environmental strategies and environmental performance in a supply chain context. We chose to collect data from manufacturing firms in Turkey. According to Zhu and Sarkis (2007), corporate and environmental manufacturing issues have not been investigated in developing economies as well as they have been in developed economies. Yet, environmental management in firms in developing economies is highly relevant for decisionmakers in both developed and developing economies. There is a global shift of (basic) manufacturing from developed economies to low-cost countries (Kinkel and Maloca, 2009; UNCTAD, 2008). In such low-cost countries, the general public is increasingly aware of environmental issues (Zhu et al., 2008a). At the same time, firms in developing economies who purchase manufactured goods from low-cost countries are increasingly held accountable for the environmental impact of their supply chain partners (Maignan et al., 2002).

Turkey is one such destination for manufacturing outsourcing and one of the biggest developing economies of the world (IMF, 2009). We selected three major sectors from the manufacturing industry which have a significant contribution to the Turkish economy: 1) chemicals and plastics, 2) food and beverage and 3) machines. In order to obtain a list of large and medium-sized companies in these sectors, we used two company directories of the Istanbul Chamber of Industry (2006) and obtained a list consisting of 368 firms. We prepared an online survey considering the many advantages it offers over mail surveys such as less cost and time required (Schaefer and Dillman, 1998) and quicker responses (Ilieva et al., 2002).

The pre-testing of the survey was done with three companies that offered suggestions as to how the phrasing of some items could be improved. All 368 companies were called to establish who the most knowledgeable informant was. Subsequently, an invitation e-mail with a link to the survey was sent to the purchasing manager or the environmental manager of all 368 companies. After sending out two e-mail reminders to non-respondents, 96 fully completed returns were obtained, resulting in a $29.9 \%$ response rate. Information about the distribution of firms by industry and size are indicated in Table 1, as well as the proportion of respondent firms holding certifications related to quality, safety, health, and environment.

\section{--- Insert Table 1 about here ---}

\subsection{Questionnaire development}

Five items were developed for each construct, based on an extensive review of the literature on corporate environmental strategies and green supply chain management (see Appendix A for the items used and their sources). Customer Pressure, Organizational Commitment, Internal Investments and External Investments were all measured with items that all used a five-point Likert-type scale ranging from (1) "not at all" to (5) "a very great extent". The construct of Proactive Environmental Strategy was measured with items using a five-point Likert-type scale ranging from (1) "not implementing it" to (5) "implementing successfully". Finally, to measure Environmental Performance, the respondents were asked to rate their success in decreasing their environmental impact relative to competitors with items using a five-point Likert-type scale ranging from (1) "not successful" to (5) "very successful".

We operationalized Environmental Investments as a second-order formative construct consisting of the first-order constructs Internal Investments (i.e., firm internal investments) and External Investments (i.e., supplier-related investments). In other words, a change in one 
of the types of investments does not necessarily mean a change in the other (Bruhn et al., 2008). We view environmental investments as an aggregate of its underlying dimensions (Edwards, 2001); in our case, internal and external investments. Use of a second-order model is in line with our main research question about the role of overall investments as a mediator of the relationship between proactive environmental strategies and environmental performance.

In the literature about environmental strategies, associations have been found between organizational size and environmental performance (Klassen and Whybark, 1999; Vachon and Klassen, 2006) Additionally, industry and ISO 14001 certificate ownership have been found to be related to environmental investments (Klassen and Vachon; 2003; Klassen and Whybark, 1999). In order to check for the robustness of our findings, we also tested our model with these control variables. We measured organizational size by number of employees, whereas we have dichotomous variables for industry membership and ISO 14001 ownership.

\subsection{Data analysis}

We tested our model using partial least squares (PLS), a structural equation modelling (SEM) technique, and used the PLS algorithms as implemented in the SmartPLS software, version 2.0M2 (Ringle et al., 2005). PLS estimation uses an iterative estimation algorithm, which consists of a series of ordinary least squares regression analyses (Chin, 1998).

As opposed to covariance-based structural equation modelling, such as LISREL, PLS estimation is component-based. As a consequence, PLS does not require multivariate normal data, places minimum requirements on measurement levels and is more suitable for small samples (Chin, 1998). As a rule of thumb, covariance-based SEM would require a sample size of 200 observations or more (Shah and Goldstein, 2006). PLS is therefore better suited for our study. In order to assure that our sample size is adequate for the analysis we used the G*Power 3 software (Faul et al., 2007) to conduct a power analysis, as proposed by Cohen et al. (1983) for the F-test, pertaining to $\mathrm{R}^{2}$ for the endogenous constructs. Assuming a large effect size $\left(f^{2}=0.35 ; R^{2}=0.26\right)$ for four predictors, a significance level $(\alpha)$ of 0.05 and a desired power $(1-\beta)$ of 0.90 , our analysis would require a sample size of 50 . For our model with control variables, the required sample size would be 63 . We exceed these thresholds with our actual sample size of 96.

PLS can handle complex problems better and avoids two problems usually faced in covariance-based SEM: inadmissible solutions and factor indeterminacy (Fornell and Bookstein, 1982). Moreover, PLS can more easily accommodate the use of formative indicators as compared to covariance-based SEM (Chin, 1998; Fornell and Larcker, 1981; Hulland, 1999; Jarvis et al., 2003). PLS is therefore better suited to test our model with a second-order formative construct. The model in PLS is analyzed and interpreted sequentially in two stages: 1) the assessment of the reliability and validity of the measurement model and 2) the assessment of the structural model (Hulland, 1999).

\section{Results}

To measure our formative construct, we adopted the two-step approach (Wilson and Henseler, 2007) to measure our formative construct, Environmental Investments. First, we estimated the latent variable scores for Internal Investments and External Investments using PLS. We specified two models, one with Internal Investments and all other first-order constructs, and one with External Investments and all other constructs. Then, we specified our final model using the latent variable scores of the two first-order constructs as formative indicators of the Environmental Investment construct. 


\subsection{Measurement model}

Adequacy of the measurement model in PLS is assessed on three aspects: 1) individual item loadings and composite reliabilities of the constructs, 2) convergent validity and 3) discriminant validity (Hulland, 1999). Regarding the item reliabilities, the results of the measurement model show that all of the reflective items have a loading of more than 0.7 , which is usually accepted as the threshold level (Hulland, 1999), except for one item in the Environmental Performance construct: "reduction of material use". The loading of this item is close to the cut-off value (0.68), and considering the content validity of the latent construct, this item is retained (see Table 2).

The loadings or weights of our formative second-order construct need to be evaluated differently. As this is a formative measure, the weights indicate the contribution of each item to forming the construct. In other words, it can be interpreted that the Internal Investments construct (0.82) contributes almost three times as much to explaining the Environmental Investments construct compared to the External Investments construct (0.29).

--- Insert Table 2 about here ---

All composite reliabilities (CR) are higher than 0.90, which is well above the recommended minimum of 0.7 . In order to evaluate construct validity, we also checked for convergent validity and discriminant validity (Gefen and Straub, 2005). Convergent validity is met when each measurement item correlates strongly with its assumed theoretical construct. It is checked in PLS by examining the average variance extracted (AVE), which shows the ratio of the sum of its measurement item variance as extracted by the construct relative to the measurement error attributed to its items (Gefen and Straub, 2005). In our case, the AVE for each construct is 0.66 or higher, well above the recommended minimum of 0.5 for convergent validity (Chin, 1998; Fornell and Larcker, 1981). Discriminant validity of the constructs is assessed to see if the construct shares more variance with its measures than it shares with other constructs in the model (Hulland, 1999). Therefore, the square roots of the AVEs (reported on the diagonal of Table 3) must be greater than the zero-order correlation coefficients with all other constructs in the model (reported off-diagonal in Table 3). This is the case for all constructs.

\section{--- Insert Table 3 about here ---}

The fit of the model is calculated with the global goodness-of-fit formula suggested in Tenenhaus et al. (2005), which is based on $\mathrm{R}^{2}$ values. This value is found by taking the square root of the product of the average communality of all constructs and the average $R^{2}$ value of the endogenous constructs, where a fit measure between 0 and 1 is calculated. For our model, this fit is 0.66 , which is well above the large effect size cut-off value of 0.36 discussed by Fornell and Larcker (1981), indicating a good fit of the model to the data.

\subsection{Structural model: hypothesis testing}

In order to test the significance of the relationships in the structural model, we used a bootstrapping procedure with 250 resamples (Tenenhaus et al., 2005) to calculate the $t$ statistics for the hypothesized relationships. The results of this analysis are shown in Table 4. The results provide support for all five of our hypotheses.

As hypothesized, the results show a strong positive relationship between Proactive Environmental Strategy and Environmental Investments $(\gamma=0.68)$. Also the path coefficient between Environmental Investments and Environmental Performance supports the positive relationship between these constructs $(\gamma=0.69)$. The $\mathrm{R}^{2}$ values also indicate the strength of 


\section{Discussion}

All five hypotheses in our conceptual model are supported. Environmental Investments have a positive impact on Environmental Performance, and is positively affected by Customer Pressure and Proactive Environmental Strategy. Proactive Environmental Strategy, in turn, is also affected by Customer Pressure and by Organizational Commitment. The results hold important findings in relation to the two intended contributions of our study; examining the mediated path from proactive environmental strategy, via environmental investments, to environmental performance, and investigating the impact of the internal and external antecedents of these strategies and investments.

First, the findings suggest that the link between proactive environmental strategy and performance is indeed mediated by actual behaviour in the form of investments. In order to test whether Environmental Investments is a full mediator of the relationship between Proactive Environmental Strategy and Environmental Performance, we used the four-step approach discussed in Kenny et al. (1998). Table 5 shows the results of this analysis. Our findings support all four conditions. Taken together, these results support our 'strategyactions-results' approach.

\section{--- Insert Table 5 about here ---}

Second, the findings also imply that there are two types of paths from Customer Pressure as a stimulus to Environmental Investments as an organizational response. First, there is a reactive path, where Customer Pressure directly affects Environmental Investments, without affecting Proactive Environmental Strategy. Managers feel the pressure put on them by customers, and they comply with such pressures by taking certain actions (internally and/or externally in collaboration with suppliers). Second, there is a proactive path, where Customer Pressure is one stimulus to develop a Proactive Environmental Strategy, which subsequently impacts Environmental Investments. This second path is not merely a compliance response, but a commitment response. This distinction is similar to that used by Falbe and Yukl (1996). In their study into response to influence attempts, they distinguish between commitment and compliance as two forms of "successful" outcomes. Commitment 
occurs when a target agrees internally, is enthusiastic about it, and is likely to exercise initiative and demonstrate unusual effort and persistence in order to carry out the request successfully. Compliance occurs when the target person carries out the requested action but is apathetic about it rather than enthusiastic, makes only a minimal or average effort, and does not show any initiative (Falbe and Yukl, 1996, pp. 639-640). Customers who attempt to influence their suppliers towards making environmental investments are advised to gauge the level of organizational commitment at their suppliers, so as to assure attitudinal commitment, rather than behavioural compliance.

The other stimulus for Proactive Environmental Strategy is Organizational Commitment. Together with Customer Pressure, it explains a substantial portion of the variation in proactiveness, which is in line with the arguments in this study that these factors are the major antecedents of proactiveness. Organizational Commitment is actually more than three times as important as Customer Pressure in explaining Proactive Environmental Strategy. It is logical that organizational commitment has a bigger impact than customer pressure, as without organizational commitment a strategy can hardly be called proactive.

On a more detailed level, the results indicate that Internal Investments have a stronger impact on Environmental Performance than External Investments, given their comparative weights in the second-order formative construct. In other words, environmental performance is first and foremost helped by investments in internal measures to reduce environmental impact through environmentally friendly product and process design, production processes and logistic processes. Nevertheless, external investments in the shape of collaborative efforts with suppliers in this domain also make a significant contribution, but the relative weights are approximately about 3-to-1.

This finding may reflect the fact that the majority of our respondent firms come from the chemicals and plastics sector or the food and beverages sector. These sectors, compared to large scale assembly industries such as the electronics and automotive industry, are relatively more integrated vertically; i.e. they typically outsource less of their production activities (Van Weele, 2005). Therefore, there is less need and opportunity to try and reduce environmental impact by working together with suppliers. Second, it may reflect that our respondents come from a developing economy, i.e. Turkey. In general, firms in developing economies are more vertically integrated than their sectoral counterparts in a developed economy (Pamukcu and De Boer, 2001).

\section{Conclusions}

In this study, we focus on the antecedents and consequences of a proactive environmental strategy. Before examining the impact of the antecedents, we first examine the consequences and suggest that a previously neglected factor, environmental investments, needs to be considered as well in this relationship. Rather than suggesting a direct link between proactive environmental strategy and environmental performance, we adopt a 'strategy-actions-results' perspective, and argue that environmental investments acts as a mediator between proactive environmental strategy and environmental performance. By considering environmental investments as a mediator in this study, we are able to explain the inconsistencies in past research regarding the impact of proactiveness on environmental performance. The results of our study suggest that developing proactive environmental strategies and making environmental investments both internally and externally really pays off. Additionally, we are able to stress the importance of organizational commitment and customer pressure on adopting proactive environmental strategy. Organizational commitment seems to have a major stake in proactiveness, which is in line with our expectations. In the 
absence of organizational commitment one would hardly expect a successful proactive strategy, which in its very nature requires going beyond off-the-shelf policies.

Our results highlight some important managerial implications. First of all, firms should bear in mind that just formulating proactive strategies is not sufficient to achieve a higher performance, and that it clearly needs to be supported by actual environmental investments. Without taking action in the form of both internal firm-specific and external supplier-related investments, there is hardly any gain from proactive environmental strategies. Our results indicate that even though internal investments impact environmental performance more than external investments, the impact of external investments is not negligible. Particularly firms that outsourced large parts of their production should not underestimate the contribution their suppliers can make to their environmental performance, and try to involve them more in their strategies by setting environmental goals and strategies together, sharing personnel and equipment related to environment, and establishing joint environmental programs.

Secondly, managers need to be aware that without organizational commitment it is not possible to implement a proactive strategy successfully. Both the commitment of top management and employees towards environmental performance improvement are necessary. In order to support organizational commitment, firms might consider encouraging crossfunctional cooperation between departments and offer environmental training for their employees.

For future research, we suggest longitudinal studies that could shed more light on the causality of the effects as hypothesized and supported in this study. These studies could examine more closely the interrelations between internal and external investments, and also consider additional factors related to supply chain (i.e. the impact of the extent of outsourcing). Future studies could also test similar models in different industries and in different countries to further increase our understanding of how developing economies differ from developed economies. 


\section{Appendix A: Questionnaire items}

Environmental Performance (Zhu and Sarkis, 2004; Zhu et al., 2008b)

During the last two years, compared to your competitors, how successful would you describe your plant/company in the following environmental activities? (1: not successful, 2: slightly successful, 3: somewhat successful, 4: successful, 5: very successful):

E1. Reduction of material use

E2. Reduction of solid (if applicable, liquid or gas) waste and hazardous materials

E3. Reduction of air emission

E4. Reduction of waste water

E5. Reduction of energy

Environmental Investments (Internal): (Klassen and Whybark, 1999; Sharma, 1998)

During the last two years, to what extent has your plant/company invested resources (money, time, people) in programs in the following areas? (1: not at all, 2: a limited extent, 3: a moderate extent, 4: a great extent 5: a very great extent):

I1. Design for disassembly, reuse, recycling, recovery of material, components, parts

I2. Environmentally friendly product design

I3. Effective management of environmental risks affecting our business

I4. Environmental improvement of packaging and transportation

I5. Improvement of our enterprise's overall environmental situation

Environmental Investments (External): (Theyel, 2001; Vachon and Klassen, 2008)

During the last two years, to what extent did your plant/company invest in the following environmental activities together with your main suppliers? (1: not at all, 2: a limited extent, 3: a moderate extent, 4: a great extent, 5: a very great extent):

S1. Setting environmental goals and strategies together with our main suppliers

S2. Establishing joint environmental programs to reduce environmental impact of our activities

S3. Environmental information sharing

S4. Sharing personnel and equipment related to environment

S5. Cooperation with our suppliers for eco-design

Proactive Environmental Strategy (Bowen et al., 2001b; Scherpereel, 2001; Zhu et al.; 2008b)

During the last two years, which of the following environmental activities has your plant/company considered or implemented? (1. not implementing it, 2. planning to consider it, 3. considering it, 4. initiating implementation, 5. implementing successfully):

P1. Going beyond basic compliance with laws and regulations on environmental issues

$\mathrm{P} 2$. A long-term environmental management system

P3. Incorporating innovative environmental management programs

P4. Environmental impact and performance assessment for our production and / or products

P5. Supplier environmental performance and commitment evaluation and audits

Customer Pressure: (Theyel, 2001; Vachon and Klassen, 2006)

During the last two years, to what extent did your plant/company face the following customer pressures related to your environmental activities? (1: not at all, 2: a limited extent, 3: a moderate extent, 4: a great extent, 5: a very great extent):

C1. Pressure to meet environmental requirements set by our main customers

C2. Requesting detailed information to assure our environmental compliance

C3. Requirement by customers to improve the environmental quality of our products

C4. Requesting us to fulfill waste reduction goals

C5. Requesting us to initiate in recycling, remanufacturing and / or re-use

Organizational Commitment: (Scherpereel, 2001; Zhu et al., 2008a)

During the last two years, to what extent did your plant/company engage in the following managerial and strategic activities related to environmental management? (1: not at all, 2: a limited extent, 3: a moderate extent, 4: a great extent 5: a very great extent):

O1. Commitment of top management for environmental management and policies

O2. Support for environmental management and policies from mid-level managers

O3. Organizational support for new environmental initiatives

O4. Cross-functional cooperation between departments for environmental improvements

O5. Environmental training for employees and employee involvement 


\section{References}

Aragón-Correa, J.A. and Sharma, S., 2003. A contingent resource-based view of proactive corporate environmental strategy. Academy of Management Review, 28 (1), 71-88.

Bakker, F. and Nijhof, A., 2002. Responsible chain management: A capability assessment framework. Business Strategy and the Environment, 11 (1), 63-75.

Banerjee, S.B., 2001. Corporate environmental strategies and actions. Management Decision, 39 (1), 36-44.

Beamon, B., 1999. Designing the green supply chain. Logistics Information Management, 12 (4), 332-342.

Bloemhof-Ruwaard, J.M., Krikke, H. and Van Wassenhove L.N. 2004. OR models for ecoeco closed-loop supply chain optimization. In: R. Dekker, M. Fleischmann, K. Inderfurth, K. and L.N. Wassenhove, eds. Reverse logistics: quantitative models for closed-loop supply chains. Vol 1, Berlin/Heiderberg: Springer-Verlag.

Bowen F.E., Cousins, P.D., Lamming, R.C.and Faruk, A.C., 2001a. Horses for courses: Explaining the gap between the theory and practice of green supply. Greener Management International, 35 (3), 41-60.

Bowen F.E., Cousins, P.D., Lamming, R.C. and Faruk, A.C., 2001b. The role of supply management capabilities in green supply. Production and Operations Management, 10 (2), 174-189.

Boyer, K.K., 1998. Longitudinal linkages between intended and realized operations strategies. International Journal of Operations and Production Management, 18 (4), 356-373.

Buysse, K. and Verbeke, A, 2003. Proactive environmental strategies: A stakeholder management perspective. Strategic Management Journal, 24 (5), 453-470.

Carr, A.S. and Kaynak, H., 2007. Communication methods, information sharing, supplier development and performance: an empirical study of their relationships. International Journal of Operations and Production Management, 27 (4), 346-370.

Carter, R.C., Ellram, L.M. and Kathryn, L.M., 1998. Environmental purchasing: Benchmarking our German counterparts. International Journal of Purchasing and Materials Management, 34 (4), 28-38.

Chin, W.W., 1998. The partial least squares approach for structural equation modeling. In: G.A. Marcoulides, eds. Modern methods for business research. London: Lawrence Erlbaum Associates, 295-336.

Cohen, J., Cohen, P., West, S.G. and Aiken, L.S., 1983. Applied multiple regression/correlation analysis for the behavioural sciences, 2 nd ed., Hillsdale, NJ: Erlbaum.

Cordeiro, J. and Sarkis, J., 1997. Environmental proactivism and firm performance: evidence from security analyst forecasts. Business Strategy and Environment, 6 (2), 104-114.

Cox, J., Sarkis, J. and Wells, W., 1999. Exploring organizational recycling market development: The Texas-Mexico border. In: M. Charter, M.J. Polonsky, eds. Greener Marketing: A Global Perspective on Greening Marketing Practice. Sheffield: Greenleaf Publishing, 381-394.

Daily, B.F. and Huang, S.C., 2001. Achieving sustainability through attention to human resource factors in environmental management. International Journal of Operations and Production Management, 21 (12), 1539-1552.

Delmas, M. and Toffel, M., 2004. Stakeholders and environmental management practices: an institutional framework. Business Strategy and the Environment, 13 (4), 209-222.

Dillman, D.A., 1999. Mail and internet surveys: The tailored design method. 2nd ed. New York: John Wiley and Sons. 
Dobni, C.B. and Luffman, G., 2003. Determining the scope and impact of market orientation profiles on strategy implementation and performance. Strategic Management Journal, 24 (6), 579-585.

Edwards, J.R.2001. Multidimensional constructs in organizational behavior research: An integrative analytical framework. Organisational Research Methods, 4 (2), 144-192.

Elkington, J., 1994. Towards the sustainable corporation: Win-win-win business strategies for sustainable development. California Management Review, 36 (2), 90-100.

Falbe, C.M. and Yukl, G., 1992. Consequences for managers of using single influence tactics and combinations of tactics. Academy of Management Journal, 35 (3), 638-652.

Faul, F., Erdfelder, E., Lang, A.G. and Buchner, A., 2007. G*Power 3: A flexible statistical power analysis for the social, behavioral, and biomedical sciences. Behavior Research Methods, 39 (2), 175-191.

Fornell, C. and Bookstein, F.L., 1982. Two structural equation models: LISREL and PLS applied to consumer exit-voice theory. Journal of Marketing Research, 19, 440-552.

Fornell, C.R. and Larcker, D.F., 1981. Structural equation models with unobservable variables and measurement error. Journal of Marketing Research, 18 (3), 39-50.

Gefen, D. and Straub, D.W., 2005. A practical guide to factorial validity using PLS-graph: Tutorial and annotated example. Comm. Association Inform. Systems, 16 (5), 91-109.

Ginsberg, A. and Venkatraman, N., 1985. Contingency perspectives of organizational strategy: A critical review of the empirical research. Academy of Management Review, 10 (3) 421-434.

González-Benito, J., 2008. The effect of manufacturing pro-activity on environmental management: an explanatory analysis. International Journal of Production Research, 46 (24), 7017-7038.

González-Benito, J. and González-Benito, Ó., 2006. A review of determinant factors of environmental proactivity. Business Strategy and the Environment, 15 (2), 87-102.

Green, K., Morton, B. and New, S., 1998. Green purchasing and supply policies: Do they improve companies' environmental performance? Supply Chain Management, 3 (2), 89-95.

Gupta, M.C., 1995. Environmental management and its impact on the operations function. International Journal of Operations \& Production Management, 15 (8), 34-51.

Hall, J., 2000. Environmental supply chain dynamics. Journal of Cleaner Production, 8 (6), 455-471.

Hart, S.L., 1995. A natural-resource-based view of the firm. Academy of Management Review, 20 (4), 986-1014.

Henriques, I. and Sadorsky, P., 1996. The determinants of an environmentally responsive firm: An empirical approach. Journal of Environmental Economics and Management, 30 (3), 381-395.

Henriques, I. and Sadorsky, P., 1999. The relationship between environmental commitment and managerial perceptions of stakeholder importance. Academy of Management Journal, 42: 87-99.

Hill, K., 1997. Supply chain dynamics, environmental issues and manufacturing firms. Environment and Planning, A 29 (7), 1257-1274.

Holt, D., 2004. Managing the interface between suppliers and organizations for environmental responsibility: An exploration of current practices in the UK. Corporate Social Responsibility and Environmental Management, 11 (2), 71-84.

Hulland, J., 1999. Use of partial least squares (PLS) in strategic management research: A review of four recent studies. Strategic Management Journal, 20 (2), 195-204. 
Humphreys, P.K., Li, W.L. and Chan, L.Y., 2004. The impact of supplier development on buyer - supplier performance. Omega: The International Journal of Management Science, 32 (2), 131-143.

Ilieva, J., Baron, S. and Healey, N.M., 2002. Online surveys in marketing research: Pros and cons. International Journal of Market Research, 44 (3), 361-378.

IMF, World Economic Outlook Report, April 2009.

Jarvis, C.B., MacKenzie, S.B. and Podsakoff, P.M., 2003. A critical review of construct indicators and measurement model misspecification in marketing and consumer research. Journal of Consumer Research, 30 (2), 199-218.

Kaplowitz, M.D., Hadlock, T.D. and Levine, R., 2004. A comparison of web and mail survey response rates. Public Opinion Quarterly, 68 (2), 94-101.

Kenny, D. A., Kashy, D. A. and Bolger, N., 1998. Data analysis in social psychology. In: D. Gilbert, S. T. Fiske and G. Lindzey, eds. Handbook of social psychology. 4th ed., Vol. 1, New York: McGraw-Hill, 233-265.

Kinkel, S. and Maloca, S., 2009. Drivers and antecedents of manufacturing offshoring and backshoring - A German perspective. Journal of Purchasing and Supply Management, 15 (3), 154-165.

Klassen, R.D., 2001. Plant-level environmental management orientation: the influence of management views and plant characteristics. Production and Operations Management, 10 (3), 257-275.

Klassen, R.D. and Angell, L.C., 1998. An international comparison of environmental management in operations: the impact of manufacturing flexibility in the U.S. and Germany. Journal of Operations Management, 16 (2), 177-194.

Klassen, R.D. and McLaughlin, C.P., 1996. The impact of environmental management on firm performance. Management Science, 42 (8), 1199-1213.

Klassen, R.D. and Vachon, S., 2003. Collaboration and evaluation in the supply chain: The impact on plant-level environmental investment. Production and Operations Management, 12 (3), 336-352.

Klassen, R.D. and Whybark, D.C., 1999. The impact of environmental technologies on manufacturing performance. Academy of Management Journal, 42 (6), 599-615.

Kleindorfer, P.R., Singhal, K. and Van Wassenhove, L.N., 2005. Sustainable operations management. Production and Operations Management, 14 (4), 482-492.

Lamming, R. and Hampson, J., 1996. The environment as a supply chain management issue. British Journal of Management, 7 (1), 45-62.

Lee, S.Y. and Klassen, R.D., 2008. Drivers and enablers that foster environmental management capabilities in small- and medium-sized suppliers in supply chains. Production and Operations Management, 17 (6), 573-586.

Lee, S.Y. and Rhee, S., 2007. The change in corporate environmental strategies: A longitudunal empirical study. Management Decision, 45 (2), 196-216.

Liu, C. and Wu, C., 2009. Environmental consciousness, reputation and voluntary environmental investment. Australian Economic Papers, 48 (2), 124-137.

Maignan, I., Hillebrand, B. and McAlister, D., 2002. Managing socially-responsible buying: How to integrate noneconomic criteria into the purchasing process. European Management Journal, 20 (6), 641-648.

Marshall, R.S., Cordano, M. and Silverman, M., 2005. Exploring individual and institutional drivers of proactive environmentalism in the US wine industry. Business Strategy and Environment, 14 (2), 92-109.

Pamukcu, T. and De Boer, P., 2001. Sources of industrial innovation in newly industrialized country: A microeconomic analysis for Turkish manufacturing industries. In: T.M. Khalil, L.A. Lefebvre and R.M. Mason, eds: Management of technology: The key to 
prosperity in the third millennium - Selected papers from the 9th International Conference on Management of Technology

Rhee, S. and Lee, S., 2003. Dynamic change of corporate environmental strategy: Rhetoric and reality. Business Strategy and the Environment, 12 (3), 175-190.

Ringle, C.M., Wende, S. and Will, S., 2005. SmartPLS 2.0 (M3) Beta, Hamburg, http://www.smartpls.de.

Rodriguez, A.M., Stank, T.P. and Lynch, D.F., 2004. Linking strategy, structure, process and performance in integrated logistics. Journal of Business Logistics, 25 (2), 65-94.

Russo, M.V. and Fouts, P.A., 1997. A resource-based perspective on corporate environmental performance and profitability. Academy of Management Journal, 40 (3), 534-559.

Schaefer, D.R., and Dillman, D.A., 1998. Development of a standard e-mail methodology: Results of an experiment. Public Opinion Quarterly, 62 (3), 378-397.

Scherpereel, C., Van Hoppen, C.S.A. and Heering, G.B.F., 2001. Selecting environmental performance indicators: The case of Numico. Greener Management International, 33 (1), 97-114.

Shah, R. and Goldstein, S., 2006. Use of structural equation modeling in operations management research: Looking back and forward. Journal of Operations Management, 24 (2), 148-169.

Sharma, S. 2000. Managerial interpretations and organizational context as predictors of corporate choice of environmental strategy. Academy of Management Journal, 43 (4) 681-697.

Sharma, S. and Vredenburg, H., 1998. Proactive corporate environmental strategy and the development of competitively valuable organizational capabilities. Strategic Management Journal, 19 (8), 729-754.

Snow, C.C. and Hambrick, D.C., 1980. Measuring organizational strategy: Some theoretical and methodological problems. Academy of Management Review, 5 (4), 527-538.

Srivastava, S.K., 2007. Green supply-chain management: A state-of-the-art literature review. International Journal of Management Reviews, 9 (1), 53-80.

Tenenhaus, M., Vinzi, V.E., Chatelin, Y.M. and Lauro, C., 2005. PLS path modelling. Computational Statistics and Data Analysis, 48 (1), 159-205.

Theyel, G. 2001. Customer and supplier relations for environmental performance. Greener Management International, 35 (3), 61-69.

UNCTAD, 2008. World investment report, New York/Geneva: United Nations.

Vachon, S., 2007. Green supply chain practices and the selection of environmental technologies. International Journal of Production Research, 45, (18-19), 4357-4379.

Vachon, S. and Klassen, R.D. 2006. Extending green practices across the supply chain: The impact of upstream and downstream integration. International Journal of Operations \& Production Management, 26 (7), 795-821.

Vachon, S. and Klassen, R.D., 2007. Supply chain management and environmental technologies: The role of integration. International Journal of Production Research, 45 (2), 401-423.

Vachon, S. and Klassen, R.D., 2008. Environmental management and manufacturing performance: The role of collaboration in the supply chain. International Journal of Production Economics, 111 (2), 299-315.

Van Weele, A.J., 2005. Purchasing and supply chain management: Analysis, planning and practice. 4th ed, London: Thomson International

Walker, H., Di Sisto, L. and McBain, D., 2008. Drivers and barriers to environmental supply chain management practices: Lessons from the public and private sectors. Journal of Purchasing and Supply Management, 14 (1), 69-85. 
Word count (before References): 8035 (including the abstract) 
Table 1: Distribution of survey respondents by industry, size and certification

\begin{tabular}{|c|c|c|c|c|c|}
\hline & Total & Percentage & & Total & Percentage \\
\hline \multicolumn{3}{|l|}{ Industry } & \multicolumn{3}{|l|}{ Size (annual sales in 2007) } \\
\hline \multicolumn{6}{|l|}{ Chemicals and } \\
\hline Food and beverages & 29 & $30.2 \%$ & 26 - 100 million NTL & 28 & $29.2 \%$ \\
\hline Machines & 23 & $24.0 \%$ & 11 - 25 million NTL & 22 & $22.9 \%$ \\
\hline \multirow[t]{2}{*}{ Total } & 96 & $100 \%$ & 1 - 10 million NTL & 21 & $21.9 \%$ \\
\hline & & & $<1$ million NTL & 3 & $3.1 \%$ \\
\hline \multicolumn{3}{|c|}{ Size (number of employees) } & Total & 96 & $100 \%$ \\
\hline$>1000$ & 3 & $3.1 \%$ & & & \\
\hline $251-1000$ & 28 & $29.2 \%$ & Certifications & & \\
\hline $101-250$ & 25 & $26.0 \%$ & ISO 9001 Certification & 86 & $89.6 \%$ \\
\hline $25-100$ & 37 & $38.5 \%$ & Other quality related certificates & 12 & $12.5 \%$ \\
\hline$<25$ & 3 & $3.1 \%$ & ISO 14001 Certification & 25 & $26.0 \%$ \\
\hline Total & 96 & $100 \%$ & Other environment related certificates & 6 & $6.3 \%$ \\
\hline
\end{tabular}

* NTL $=$ New Turkish Lira; 1 NTL is approximately equal to $0.50 €$ (September, 2010). 
Table 2. Summary of measurement scales

\begin{tabular}{|c|c|c|c|c|c|}
\hline Items & Mean & Std. dev. & $\begin{array}{c}\text { Item } \\
\text { Loading }\end{array}$ & $\begin{array}{l}\text { Composite } \\
\text { reliability }\end{array}$ & AVE \\
\hline Environmental performance & & & & 0.90 & 0.66 \\
\hline E1 & 3.19 & 1.10 & 0.68 & & \\
\hline $\mathrm{E} 2$ & 3.73 & 0.98 & 0.84 & & \\
\hline E3 & 3.84 & 0.99 & 0.86 & & \\
\hline E4 & 3.84 & 0.97 & 0.85 & & \\
\hline E5 & 3.58 & 1.07 & 0.80 & & \\
\hline Internal Investments & & & & 0.92 & 0.71 \\
\hline I1 & 3.06 & 1.14 & 0.79 & & \\
\hline $\mathrm{I} 2$ & 3.14 & 1.19 & 0.84 & & \\
\hline I3 & 3.10 & 1.19 & 0.90 & & \\
\hline I4 & 3.35 & 1.06 & 0.81 & & \\
\hline I5 & 3.64 & 0.97 & 0.86 & & \\
\hline External investments & & & & 0.93 & 0.72 \\
\hline $\mathrm{S} 1$ & 2.07 & 1.11 & 0.87 & & \\
\hline $\mathrm{S} 2$ & 1.93 & 1.15 & 0.82 & & \\
\hline S3 & 2.99 & 1.20 & 0.84 & & \\
\hline $\mathrm{S} 4$ & 2.39 & 1.25 & 0.84 & & \\
\hline S5 & 2.49 & 1.33 & 0.86 & & \\
\hline Proactive environmental strategies & & & & 0.92 & 0.70 \\
\hline $\mathrm{P} 1$ & 3.72 & 1.29 & 0.84 & & \\
\hline $\mathrm{P} 2$ & 3.39 & 1.23 & 0.85 & & \\
\hline P3 & 3.00 & 1.31 & 0.86 & & \\
\hline $\mathrm{P} 4$ & 3.40 & 1.33 & 0.85 & & \\
\hline P5 & 2.83 & 1.36 & 0.80 & & \\
\hline Customer Pressure & & & & 0.95 & 0.79 \\
\hline $\mathrm{C} 1$ & 2.57 & 1.30 & 0.87 & & \\
\hline $\mathrm{C} 2$ & 2.60 & 1.17 & 0.92 & & \\
\hline $\mathrm{C} 3$ & 2.52 & 1.24 & 0.91 & & \\
\hline $\mathrm{C} 4$ & 2.67 & 1.40 & 0.87 & & \\
\hline C5 & 2.84 & 1.36 & 0.86 & & \\
\hline Organizational Commitment & & & & 0.96 & 0.82 \\
\hline $\mathrm{O} 1$ & 3.46 & 1.17 & 0.92 & & \\
\hline $\mathrm{O} 2$ & 3.42 & 1.11 & 0.91 & & \\
\hline $\mathrm{O} 3$ & 2.89 & 1.21 & 0.92 & & \\
\hline O4 & 2.95 & 1.09 & 0.89 & & \\
\hline O5 & 3.16 & 1.18 & 0.89 & & \\
\hline
\end{tabular}


Table 3: Discriminant and convergent validity

\begin{tabular}{llcccccc}
\hline & $\mathbf{R}^{\mathbf{2}}$ & $\mathbf{1 .}$ & $\mathbf{2 .}$ & $\mathbf{3 .}$ & $\mathbf{4 .}$ & $\mathbf{5 .}$ \\
\hline 1. & Environmental Performance & $69 \%$ & 0.81 & & & & \\
2. & Environmental Investments & $58 \%$ & 0.69 & $\mathrm{n} / \mathrm{a}$ & & & \\
3. & Proactive Environmental Strategies & $49 \%$ & 0.51 & 0.79 & 0.84 & & \\
4. & Customer Pressure & $\mathrm{n} / \mathrm{a}$ & 0.38 & 0.58 & 0.54 & 0.89 & \\
5. & Organizational Commitment & $\mathrm{n} / \mathrm{a}$ & 0.55 & 0.81 & 0.78 & 0.50 & 0.90 \\
\hline
\end{tabular}


2

3

Table 4: Summary of findings

\begin{tabular}{|c|c|c|c|c|c|}
\hline & Independent variable & Dependent variable & $\begin{array}{c}\text { Path } \\
\text { coefficient }\end{array}$ & t- statistic & $\begin{array}{l}\text { Hypothesis } \\
\text { supported? }\end{array}$ \\
\hline $\mathrm{H} 1(+)$ & $\begin{array}{l}\text { Environmental } \\
\text { Investments }\end{array}$ & $\begin{array}{l}\text { Environmental } \\
\text { Performance }\end{array}$ & 0.69 & 7.93 & Yes \\
\hline $\mathrm{H} 2(+)$ & $\begin{array}{l}\text { Proactive Environmental } \\
\text { Strategy }\end{array}$ & $\begin{array}{l}\text { Environmental } \\
\text { Investments }\end{array}$ & 0.68 & 12.70 & Yes \\
\hline H3 (+) & $\begin{array}{l}\text { Customer } \\
\text { Pressure }\end{array}$ & $\begin{array}{l}\text { Environmental } \\
\text { Investments }\end{array}$ & 0.20 & 2.79 & Yes \\
\hline $\mathrm{H} 4(+)$ & $\begin{array}{l}\text { Customer } \\
\text { Pressure }\end{array}$ & $\begin{array}{l}\text { Proactive Environmental } \\
\text { Strategy }\end{array}$ & 0.20 & 2.89 & Yes \\
\hline H5 (+) & $\begin{array}{l}\text { Organizational } \\
\text { Commitment }\end{array}$ & $\begin{array}{l}\text { Proactive Environmental } \\
\text { Strategy }\end{array}$ & 0.69 & 12.12 & Yes \\
\hline
\end{tabular}


Table 5: Mediation test (based on Kenny et al., 1998)

\begin{tabular}{lccc}
\hline Model* $^{*}$ & Path & $\begin{array}{c}\text { Path } \\
\text { Coefficient }\end{array}$ & $\begin{array}{c}\text { T- } \\
\text { statistic** }^{* *}\end{array}$ \\
\hline $1 . \mathrm{X} \rightarrow \mathrm{Y}$ & $\mathrm{X} \rightarrow \mathrm{Y}$ & 0.52 & 6.36 \\
$2 . \mathrm{X} \rightarrow \mathrm{M}$ & $\mathrm{X} \rightarrow \mathrm{M}$ & 0.80 & 23.77 \\
$3 . \mathrm{X}, \mathrm{M} \rightarrow \mathrm{Y}$ & $\mathrm{M} \rightarrow \mathrm{Y}$ & 0.76 & 8.50 \\
& $\mathrm{X} \rightarrow \mathrm{Y}$ & -0.08 & 0.80 (n.s.) \\
$4 . \mathrm{X} \rightarrow \mathrm{M} ; \mathrm{M} \rightarrow \mathrm{Y} ; \mathrm{X} \rightarrow \mathrm{Y}$ & $\mathrm{X} \rightarrow \mathrm{M}$ & 0.79 & 22.95 \\
& $\mathrm{M} \rightarrow \mathrm{Y}$ & 0.78 & 7.33 \\
& $\mathrm{X} \rightarrow \mathrm{Y}$ & -0.11 & 0.94 (n.s.) \\
\hline
\end{tabular}

$* \mathrm{X}=$ Proactive Environmental Strategy, $\mathrm{Y}=$ Environmental Performance, $\mathrm{M}=$ Environmental Investments

** All paths are significant at $\mathrm{p}<0.01$, unless indicated (n.s.) 
Figure 1: Conceptual model

Drawn in: Microsoft Office Powerpoint 2007

Font used: Times New Roman

Font size: 16

Saved as: JPEG 


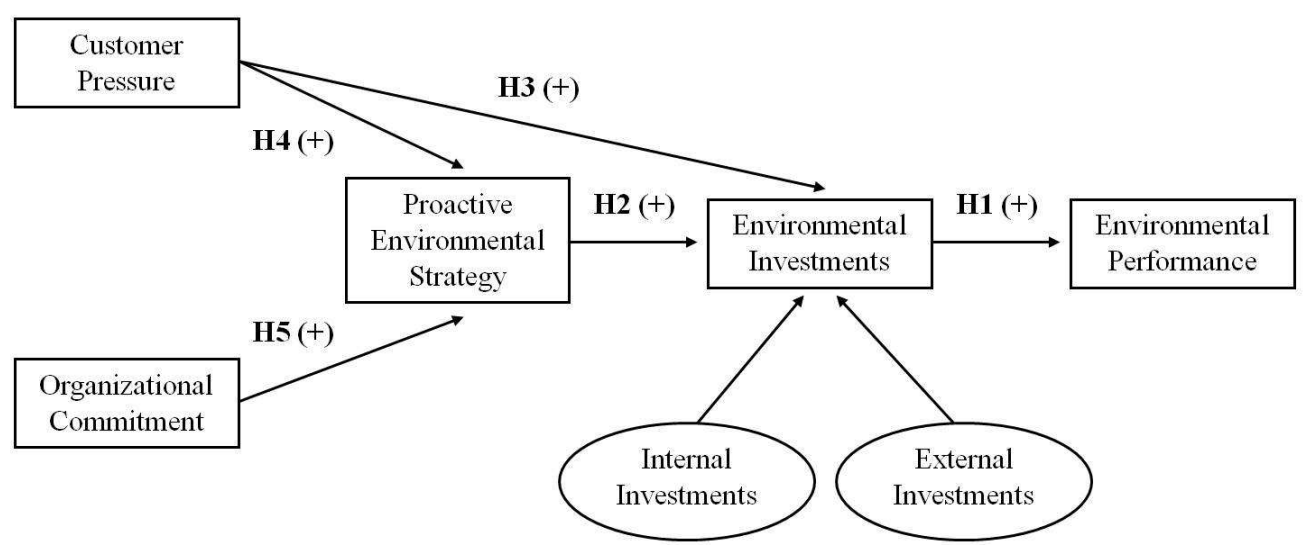

$244 \times 110 \mathrm{~mm}(150 \times 150 \mathrm{DPI})$ 